\title{
Equity Financing Strategy and the Performance of Small and Medium Enterprises in Kenya
}

\author{
John Messo Raude ${ }^{1}$, Wekesa Wesonga ${ }^{1} \&$ Peter Wawire $^{1}$ \\ ${ }^{1}$ Department of Business Management, School of Graduate Studies, Masinde Muliro University of Science and \\ Technology, Kenya \\ Correspondence: John Messo Raude, Department of Business Management, School of Graduate Studies, \\ Masinde Muliro University of Science and Technology, Kenya. E-mail: johnmesso@yahoo.com
}

Received: January 27, 2015

Accepted: February 5, 2015

Online Published: March 27, 2015

doi:10.5539/ijbm.v10n4p193

URL: http://dx.doi.org/10.5539/ijbm.v10n4p193

\begin{abstract}
The SMEs play an important role in economic growth and development in Kenya. However, in Kenya, SMEs are faced with survival problem. Their rate of failure is high and alarming. It is from this background that this study sought to investigate the cause of this failure by ascertaining the linkage between Equity Financing Strategy and the Performance of SMEs in Kakamega Municipality, Kenya. The Research Problem was formulated to answer the question; what are the Effects of Equity Financing Strategy on the Performance of SMEs? In so doing, the study ascertained causal linkage between Equity Financing Strategy, and the Performance; moderated by types of ownership and Sizes of Firms. To achieve desired results, this study employed a Descriptive Survey Research Design that employed a questionnaire with dichotomous questions to collect data from the respondents and made interviews with top management of the respective enterprises. This study was of significance to stake holders in financial sector, investors, business community, the government and the general public by: (1), providing a better understanding for designing lending policy, (2), providing a mechanism for regulating and controlling volume of credit to SMEs, (3), complementing the existing studies and contributing to knowledge on optimization of performance and (4), strengthening further research in this area. The study found evidence of strong correlation between Equity Financing Strategy and the Performance of SMEs. It also found that SMEs in Kakamega Municipality, Kenya were "financially starved".
\end{abstract}

Keywords: equity, financing strategy, performance, SMEs, profitability, tax liability, solvency

\section{Introduction}

This study sought to ascertain the effects of Equity Financing Strategy on the Performance of Small and Medium Enterprises (SMEs) in Kakamega Municipality, Kenya. In Kenya, SMEs rely heavily on primary sources of finance in financing their activities. This is because obtaining funds from secondary sources pose challenges. For SMEs to survive and grow, they need a well strategized financial structure. Financing Strategy is understood as the entrepreneur's goal in securing financing that identify the appropriate mix of funds with the least cost to the business and the fewest restrictions on business operations. A firm's Financing Strategy consists of the debt and equity used to finance its assets, with a minimum weighted-average cost of finance and thereby maximize its value. Equity financiers seek to retain as large a share of ownership in the firm as possible, so as to realize returns on the investment and innovation and to maintain business control.

The Performance of SMEs in Kenya has been a subject of growing interest in the field of finance due to their high rate of failure. The subjective measure of how well a SME uses its assets from its primary mode of business to generate revenues is referred to as 'Performance'. The concept of SMEs Performance covers both what has been achieved and how it has been achieved. Profitability, Tax Liability, Solvency, Value of the Firm and Growth in Sales were used in this study as key Performance indicators (KPIs). Kayanula and Quartey (2000) observe that SMEs are vital for development because they encouraged entrepreneurship, generate employment, and reduce poverty. On the other hand, the World Bank (2006) found that SMEs make up approximately 81 percent of Africa's private sector firms, with 51 percent being small-scale and 31 percent being medium-sized. These are collaborated by; (1), the findings of the World Bank surveys in Sub-Sahara Africa in 2009, which found that SMEs contributed to over 50 percent of new jobs in Sub-Sahara Africa in 2009, and, (2), a recent study by Miura, (2013), which found that SMEs in Japan numbered 4.2 million and accounted for 99.7 percent of all firms 
compared to the 0.3 percent of large firms in 2006, and that SMEs employed 42 million people, which is 78 percent of total employment. SMEs are therefore the prime vehicle for economic development in both developed and developing nations, and which should be rescued from collapsing.

This study was based on the theoretical pronouncement of Modigliani and Millers (1958). His two main strands, namely, the Static Trade-off Theory, and the Pecking Order Theory form the basis of the study. The Static Trade-off theory states that a firm can reach its optimum level of debt when its marginal benefit is equal to its marginal cost. Myers' (1984) Pecking Order Theory, on the other hand, talks about asymmetry information in corporations, especially in small firms and advocates the use of internal financing to external financing until the internal financing is unavailable. It relates to how conveniently and easily a firm can access capital through internal financing (retained profit).

Myers and Majluf (1984) emphasizes on frictions due to asymmetric information between managers and outside investors. In the Pecking Order Model, a financial hierarchy descends from internal funds, to debt; to external equity.This argument is supported by Green et al. (2002), who found that most firms had shifted their development strategies towards a greater reliance on the use of organized financial markets to finance their assets.

From the foregoing there was need for this study to heavily rely on these theoretical approaches in ascertaining the causal linkage between Equity Financing Strategy and the Performance of SMEs.

\section{Literature Review}

\subsection{Theories on Equity Financing Strategy}

The study applied theories and past studies founded on Modigliani and Miller, (1958). Of his four conflicting theories, the most important in this study were: the Static Trade-off, the Pecking Order, and the Signalling Theories. Myers (op. cit.) divided the contemporary thinking on financing strategy into the first two theoretical currents; the Static Trade-off and the Pecking Order.

\subsubsection{The Static Trade-off Theory}

Under the Static Trade-off of Financing Strategy (also referred to as the Tax Based Theory), Baxter, (1967) and Altman, (2002), noted that optimal financing strategy is obtained where the net tax advantage of debt financing balances leverage related costs such as financial distress and bankruptcy, holding the firm's assets and investment decisions constant. In view of this theory, issuing equity finance means moving away from the optimum and should therefore be considered as not good. Myers (op. cit.) had found that firms adopting Static Trade-off were regarded as setting a target debt-to-value ratio with a gradual attempt to achieve it. He however, suggested that managers will be reluctant to issue equity finance if they feel it is undervalued in the market. The consequence is that investors perceive equity issues to occur only if equity is either fairly priced or overpriced. As a result investors tend to react negatively to an equity issue and management is reluctant to issue equity.

\subsubsection{The Pecking Order Theory}

The Pecking Order Theory (also referred to as the Information Asymmetry Theory) was proposed by Myers (op. cit.), and Myers and Majluf op. cit. It states that firms prefer to finance new investment first internally with retained earnings, then with debt, and finally with issue of new equity. He argues that an optimal Financing Strategy is difficult to define as equity appears at the top and the bottom of the 'pecking order'. Internal funds incur no flotation costs and require no disclosure of the firm's proprietary financial information that may include the firm's potential investment opportunities and gains that are expected to accrue from undertaking investments. They pointed out that underpricing would be the best result of less information held by potential investor vis-a-vis management with respect to the expected cash flows from the firm's assets, both current and future. Considering this information asymmetry, investors would infer that the management would issue equity only when it is overpriced. Thus the newly issued equity might be sold at a discount. This would be regarded as a wealth transfer from existing investors to the new ones. This problem could be avoided if the firms use internally generated resources, such as retained earnings.

\subsubsection{Signaling Theory}

The impact of the signaling factor as already discussed in the Pecking Order Theory is the problem of the underpricing of equity. If a firm issues equity instead of debt for financing its new projects, investors will interpret the signal negatively. Since managers have superior information about the firm than investors, they might issue equity when it is overpriced.

\subsection{Empirical Studies}


Several empirical studies on Financing Strategy indicate a negative relationship between Financing Strategy and the Performance. Studies carried by Rajan and Zingales, op. cit., and Booth et al. (2001) reported negative relationship between Financing Strategy and the Performance. On the contrary, Roden and Lewellen, (1995); and Berger, Allen, Bonaccorsi and Emilia, (2006), reported positive relationship between Financing Strategies and firm's Performance. Similarly, Zeitun and Tian (op. cit.), found out that firm's Financing Strategy have a significant and negative impact on the firm's Performance measures in both the accounting and the market.

Study by Murinde et al. (2004) observed that retentions of profits are the principal source of finance. Earlier, Titman and Wessel, op. cit. and Barton et al. (1989), had found that firms with high profit rates, all things being equal, would maintain relatively lower debt ratios since they are able to generate such funds from internal sources. MacKie-Mason, (1990) on the other hand studied the tax effect on corporate financing decisions and provided evidence of substantial tax effect on the choice between Debt and Equity Financings.

\section{Research Methodology}

\subsection{Research Design}

This study employed a Descriptive Survey Research Design in which a sample size of 95 of the target population, computed using Nasiuma's (2002) formula was selected. The study covered a period of five years from 2009 to 2013. This design was useful to this study because it intensively described and analyzed the data, and provided descriptive and exploratory methods and results.

\subsection{Target Population}

The study targeted a population of about 2,713 enterprises that were operational in December, 2013 in Kakamega Municipality, Kenya. These comprised of SMEs whose annual turnover was Kshs 50 million or less, number of employees was 100 or less and / or total assets base was Kshs. 100 million or less.

\subsection{Sample Size}

This study applied Nasiuma (op. cit.) formula in determining sample size;

$$
n=(N C Y 2) /(C Y 2+(N-1) e 2)
$$

Where $\mathrm{N}$ is target population, $\mathrm{CY}$ is coefficient of variation (that is 0.5 ) and e is the tolerance at desired level of confidence, in this case it will be 0.05 at $95 \%$ confidence level. Firstly the whole population was divided according to category of enterprise as given in Table 1 . Then a sample using the above formula was taken from each category for survey from enterprises that qualified within the definition of SMEs.

Table 1. Population of the types of enterprises in Kakamega Municipality, Kenya

\begin{tabular}{lll}
\hline Enterprise & Target Population & Sample Size \\
\hline Wholesale / Retail Trade & 1,437 & 50 \\
Transport & 44 & 2 \\
Petrol Stations & 58 & 2 \\
Agricultural and Mining & 59 & 2 \\
Hotels, Restaurants, Bars and Entertainment & 275 & 10 \\
Professional Services & 635 & 22 \\
Financial & 9 & 0 \\
Education and Learning Institutions & 65 & 2 \\
Health and Medical & 27 & 1 \\
Industrial & 104 & 4 \\
Total & 2,713 & 95 \\
\hline
\end{tabular}

\subsection{Sampling Procedure}

Since the target population in this study was large, this study used sampling as a feasible means of collecting data. For the reliability of data, the population was stratified by categorizing enterprises based on ownership and size. The data collected was also grouped based on year of operation. This was necessary to obtain a set of data of observation made at different periods of time, between the years 2009 and 2013.

\subsection{Data Collection Instruments}

Data was collected by administering a questionnaire and examining figures from few records that SMEs 
maintained.

\subsection{Instrument Validity}

Data collection instruments in this study were tested through a pilot study and necessary amendments made thereafter.

\subsection{Instrument Reliability}

Reliability of a test (instrument) was expressed as a coefficient with values varying between zero and one; where zero indicates no reliability and one indicates perfect reliability.

In this study, the instrument was subjected to Karl Pearson's Product Moment correlation coefficient formula below.

$$
\mathrm{r}=\frac{n \sum x y-\sum x \sum y}{\left.\sqrt{\left\{n \sum x^{2}-\left(\sum x\right)^{2}\right.}\right\} \sqrt{\left\{n \sum y^{2}-\left(\sum y\right)^{2}\right\}}}
$$

Where: $\mathrm{r}=$ reliability coefficient;

$\mathrm{n}=$ number of respondents;

$\mathrm{X}=$ total score of the test administration;

$\mathrm{Y}=$ total score of the retest administration.

\subsection{Data Collection Procedure}

Data collection was carried out on 95 sampled SMEs categorized according to: (1), Type of ownership. (2), Sizes of enterprise and (3), Years of operation. Data collection problems were minimized through pilot-testing and pre-testing, validity / quality checks, tabulation and monitored flexibility. Rigor related to instrument protocol development were paid attention to validity, intrusiveness (the Hawthorne effect) and tabulation. In addition, attention were paid to distinguish between collecting subjective and objective data, information on the formal and the informal organizational structures and processes and the differences between collecting facts vs. opinions vs. interpretations. Incomplete, missing or unusable data corrected immediately.

\subsection{Data Analysis}

In this study, for the purpose of achieving the main research objectives, and based on the nature of the data collected, use of panel data analysis and parametric statistical techniques for data analysis was employed. The analysis made use of the data which had both time and cross section dimensions. Panel data analysis techniques were used to analyze data over the period. Venn diagrams were used to shows all possible logical allocation and intersection of Strategies that lead to "Mixed Financing Strategies". Data was also analyzed quantitatively according to: (1), Year of operation (2), Performance factor, (3), Ownership, and (4), Size. This was followed by obtaining descriptive statistics; by finding means and standard deviations.

\section{Presentation of Results}

\section{1 Venn Diagrams}

To achieve the desired results, this study employed the technique of Venn (1880) diagrams to logically analyze Strategies used by the respondents to finance their enterprises. These are shown in figures 1 to 5; covering the period 2009-2013.

Figure 1 show that 14 of the respondents financed their enterprises using Equity Strategy alone in year 2009. 


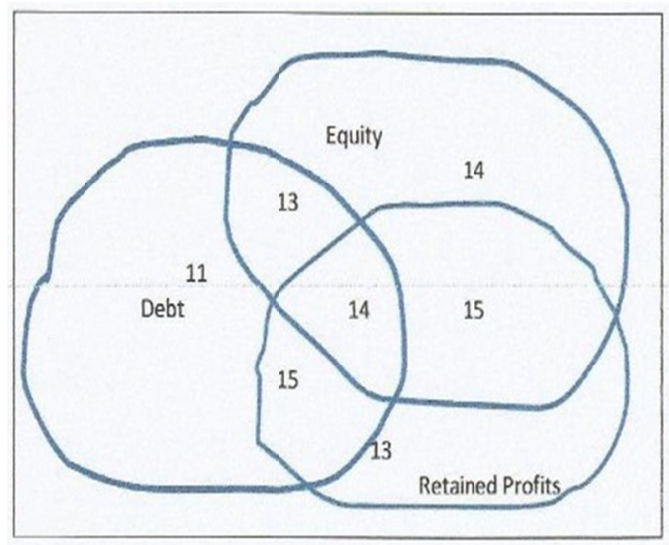

Figure 1. Venn Diagram showing financing strategies in the year 2009

Figure 2 show that 15 of the respondents financed their enterprises using Equity Strategy alone in year 2010.

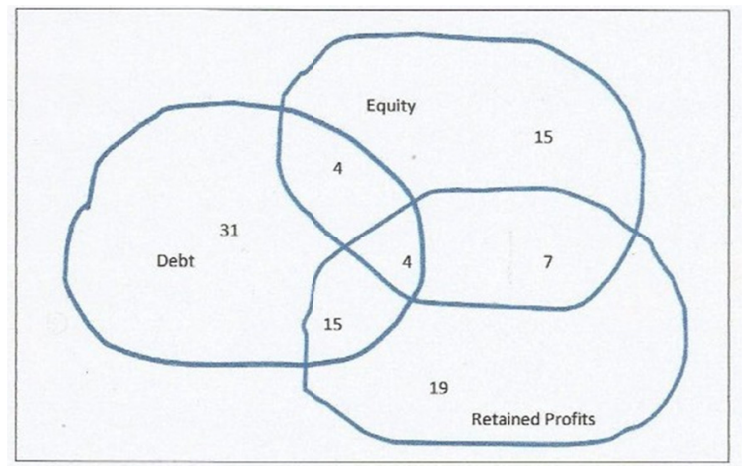

Figure 2. Venn Diagrams showing financing strategies in the year 2010

Figure 3 show that 16 of the respondents financed their enterprises using Equity Strategy alone in year 2011

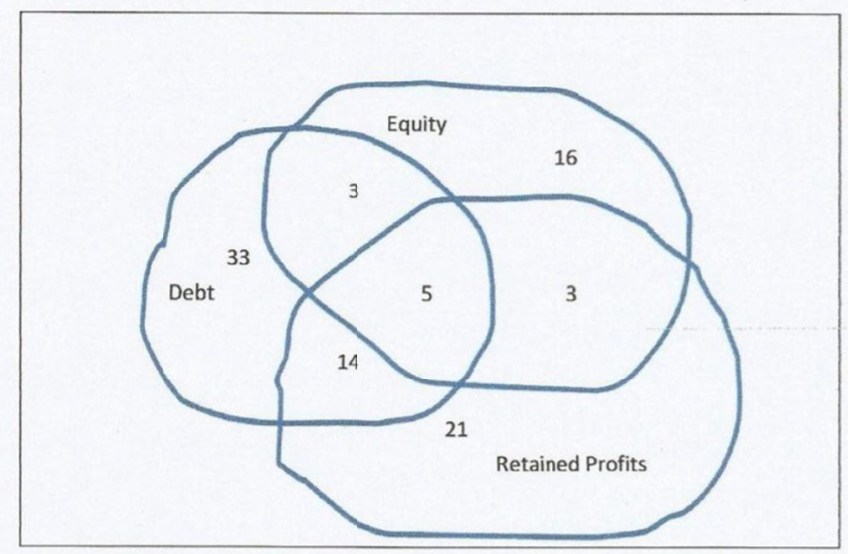

Figure 3. Venn Diagrams showing financing strategies in the year 2011

Figure 4 show that 17 of the respondents financed their enterprises using Equity Strategy alone in year 2012. 


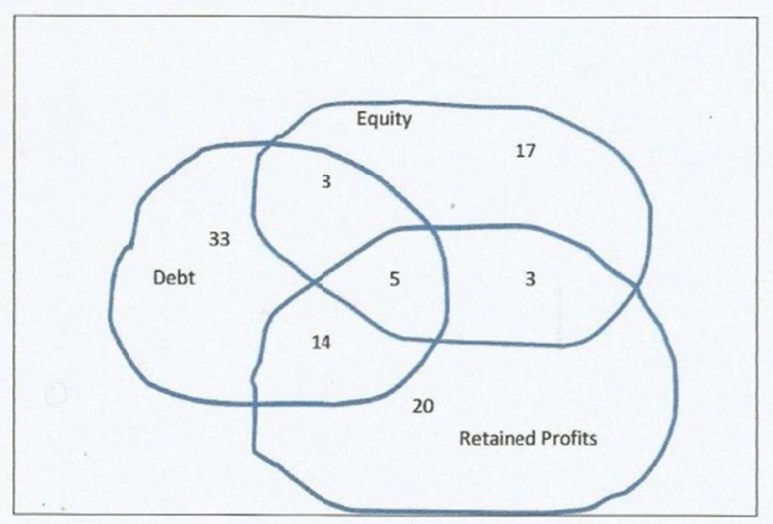

Figure 4. Venn Diagrams showing financing strategies in the year 2012

Figure 5 show that 18 of the respondents financed their enterprises using Equity Strategy alone in year 2013.

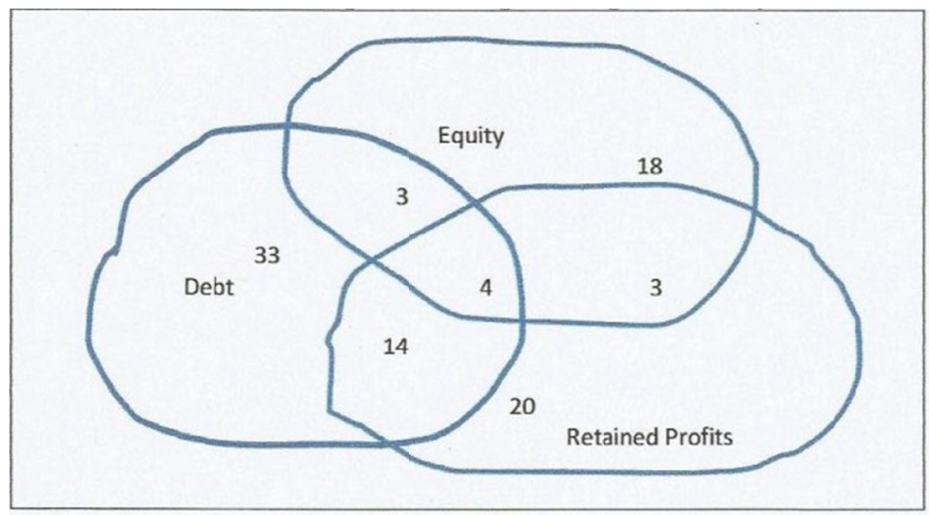

Figure 5. Venn Diagrams showing financing strategies in the year 2013

Table 2. Analysis of data from Venn Diagrams on financing strategy of SMEs over the past five years

\begin{tabular}{lllllllll}
\hline Year/ Strategy & $\mathrm{E}$ & $\mathrm{D}$ & $\mathrm{R}$ & $\mathrm{E} \cap \mathrm{D} \cap \mathrm{R}$ & $\mathrm{E} \cap \mathrm{D}$ & $\mathrm{E} \cap \mathrm{R}$ & $\mathrm{D} \cap \mathrm{R}$ & Total \\
\hline 2009 & 14 & 11 & 13 & 14 & 13 & 15 & 15 & 95 \\
2010 & 15 & 31 & 19 & 4 & 4 & 7 & 15 & 95 \\
2011 & 16 & 33 & 21 & 5 & 3 & 3 & 14 & 95 \\
2012 & 17 & 33 & 20 & 5 & 3 & 3 & 14 & 95 \\
2013 & 18 & 33 & 20 & 4 & 3 & 3 & 14 & 95 \\
Total & 80 & 141 & 93 & 32 & 26 & 31 & 72 & 475 \\
Mean. & 16 & 28.2 & 18.6 & 6.4 & 5.2 & 6.2 & 14.4 & 95 \\
Mean\% & $17 \%$ & $30 \%$ & $20 \%$ & $7 \%$ & $5 \%$ & $7 \%$ & $15 \%$ & \\
\hline
\end{tabular}

Key: E = Equity Financing, D = Debt Financing, $R=$ Retained Profits;

$E \cap D \cap R=a$ combination of Equity, Debt and Retained Profit Financings;

$\mathrm{E} \cap \mathrm{D}=\mathrm{a}$ combination of Equity and Debt Financings;

$\mathrm{E} \cap \mathrm{R}=$ a combination of Equity and Retained Profit Financings;

$\mathrm{D} \cap \mathrm{R}=\mathrm{a}$ combination of Debt and Retained Profit Financings.

\subsection{Statistical Analysis}

The results in Table 2 shows that on average 17 percent of the respondents employed Equity Financing Strategy a lone to fund the assets of their enterprises over the past five years. 


\subsection{The Effects of Equity Financing on the Performance of SMEs}

Table 3. Statistical analysis of percentage of the amount of funding over the past five years

\begin{tabular}{|c|c|c|c|c|c|c|c|}
\hline Amount (Million) & Equity & Debt & Retained Profits & $E \cap D \cap R$ & $E \cap D$ & $\mathrm{E} \cap \mathrm{R}$ & $\mathrm{D} \cap \mathrm{R}$ \\
\hline $0 \leq 20$ & $92 \%$ & $35 \%$ & $52 \%$ & $77 \%$ & $71 \%$ & $43 \%$ & $27 \%$ \\
\hline $20 \leq 40$ & $8 \%$ & $24 \%$ & $24 \%$ & $23 \%$ & $29 \%$ & $57 \%$ & $20 \%$ \\
\hline $40 \leq 60$ & $0 \%$ & $19 \%$ & $13 \%$ & $0 \%$ & $0 \%$ & $0 \%$ & $23 \%$ \\
\hline $60 \leq 80$ & $0 \%$ & $16 \%$ & $5 \%$ & $0 \%$ & $0 \%$ & $0 \%$ & $18 \%$ \\
\hline $80 \leq 100$ & $0 \%$ & $6 \%$ & $5 \%$ & $0 \%$ & $0 \%$ & $0 \%$ & $12 \%$ \\
\hline Total & $100 \%$ & $100 \%$ & $100 \%$ & $100 \%$ & $100 \%$ & $100 \%$ & $100 \%$ \\
\hline
\end{tabular}

The results in table 3 shows that 92 percent of Equity funding was less than Kshs. 20 million, 8 percent was 20 million and less than 40 million.

\subsection{Regression Analysis}

This study examined the trends of the Financing Strategies over the past five years by finding the Slopes of their regression curves. The results of the slopes are given in Table 4. The results show a positive slope of 0.8 for Equity Financing Strategy over the past five years, indicating a steady increase in the number of respondents who financed their enterprises using Equity.

Table 4. The slope of the financing strategy curves (2009-2013)

\begin{tabular}{lllll}
\hline Financing Strategy & $\mathrm{E}$ & $\mathrm{S}$ & Diff & Slope $=(\mathrm{E}-\mathrm{S}) / \mathrm{T}$ \\
\hline Equity & 18 & 14 & 4 & 0.8 \\
Debt & 33 & 24 & 9 & 1.8 \\
Retained Profits & 20 & 14 & 6 & 1.2 \\
Equity, Debt \& Retained Profits & 4 & 8 & -4 & -0.8 \\
Equity \& Debt & 3 & 4 & -1 & -0.2 \\
Equity \& Retained Profits & 3 & 5 & -2 & -0.4 \\
Debt \& Retained Profits & 14 & 26 & -12 & -2.4 \\
\hline
\end{tabular}

Key: $\mathrm{E}=$ End of period data; $\mathrm{S}=$ Start of period data; $\mathrm{T}=$ Time -5 years $(2009-2013)$.

\subsection{Correlation}

There was evidence of significant positive correlation between Equity Financing Strategy and the Performance variables of Enterprises over the past five years as shown in Tables 5 to 8 . They all gave the degree of association of 1 as follows:

Table 5 shows a strong relationship between Equity Financing Strategy and Profitability of the Enterprises.

Table 5. Relationship between equity financing and the profitability

\begin{tabular}{|c|c|c|c|c|}
\hline Equity (x) & & fx & Profitability (y) & fy \\
\hline Mid points & & No. of Respondents & Mid points & No. of Respondents \\
\hline 10 & & 7 & 0.5 & 0 \\
\hline 30 & & 0 & 1.5 & 2 \\
\hline 50 & & 0 & 2.5 & 4 \\
\hline 70 & & 0 & 3.5 & 1 \\
\hline 90 & & 0 & 4.5 & 0 \\
\hline 250 & & 7 & 12.5 & 7 \\
\hline Mean $\mathrm{x}$ & & 10.00 & & \\
\hline Mean y & 2.36 & & & \\
\hline Standard deviation & 7.14 & & & \\
\hline Correlation $\mathrm{r}$ & 1.00 & & & \\
\hline
\end{tabular}


Table 6. Relationship between equity financing and tax liability

\begin{tabular}{llll}
\hline $\mathrm{x}$ & $\mathrm{f}$ & $\mathrm{y}$ & $\mathrm{f}$ \\
Mid points & No. of Respondents & Mid points & No. of Respondents \\
\hline 10 & 7 & 0.5 & 7 \\
30 & 0 & 1.5 & 0 \\
50 & 0 & 2.5 & 0 \\
70 & 0 & 3.5 & 0 \\
90 & 0 & 4.5 & 0 \\
250 & 7 & 12.5 & 7 \\
\hline Mean(x) & 10 & Mean(y) & 0.5 \\
Standard deviation 7.14 & & Standard deviation 2.36 & \\
Correlation r 1 & & & \\
\hline
\end{tabular}

The results of Table 6 show a strong relationship between Equity Financing Strategy and Tax liability of the Enterprises.

Table 7. Relationship between equity financing and the solvency of the firm

\begin{tabular}{llll}
\hline $\mathrm{x}$ & $\mathrm{fx}$ & $\mathrm{y}$ & $\mathrm{fy}$ \\
Mid points & No. of Respondents & Mid points & No. of Respondents \\
\hline 10 & 7 & 0.5 & 6 \\
30 & 0 & 1.5 & 1 \\
50 & 0 & 2.5 & 0 \\
70 & 0 & 3.5 & 0 \\
90 & 0 & 4.5 & 0 \\
250 & 7 & 12.5 & 7 \\
\hline Mean 10 & & Mean & 0.64 \\
Standard deviation 7.14 & Standard deviation 0.755 & \\
Correlation r 1 & & \\
\hline
\end{tabular}

The results of Table 7 show a strong relationship between Equity Financing Strategy and Solvency of the Firms.

Table 8. Relationship between equity financing and value of the firm

\begin{tabular}{llll}
\hline $\mathrm{x}$ & $\mathrm{fx}$ & $\mathrm{y}$ & $\mathrm{fy}$ \\
Mid points & No. of Respondents & Mid points & No. of Respondents \\
\hline 10 & 7 & 0.5 & 7 \\
30 & 0 & 1.5 & 0 \\
50 & 0 & 2.5 & 0 \\
70 & 0 & 3.5 & 0 \\
90 & 0 & 4.5 & 0 \\
250 & 7 & 12.5 & 7 \\
\hline Mean & 10.00 & Mean 0.50 & \\
Standard deviation 7.14 & & Standard deviation 0.00 & \\
Correlation r 1 & & & \\
\hline
\end{tabular}

The results of Table 8 show a strong relationship between Equity Financing Strategy and Value of the Firms. 
Table 9. Relationship between equity financing and growth in sales

\begin{tabular}{llll}
\hline $\mathrm{x}$ & $\mathrm{fx}$ & $\mathrm{y}$ & $\mathrm{f}$ \\
Mid points & No. of Respondents & Mid points & No. of Respondents \\
\hline 10 & 7 & 0.5 & 2 \\
30 & 0 & 1.5 & 3 \\
50 & 0 & 2.5 & 2 \\
70 & 0 & 3.5 & 0 \\
90 & 0 & 4.5 & 0 \\
250 & 7 & 12.5 & 7 \\
\hline Mean 10 & & Mean 1.5 \\
Standard deviation 7.14 & & Standard deviation 0.755 \\
Correlation r 1 & & & \\
\hline
\end{tabular}

The results of Table 9 show a strong relationship between Equity Financing Strategy and Growth in sales.

Table 10. Analysis of variance

\begin{tabular}{llll}
\hline & $\begin{array}{l}\text { Equity Financing } \\
\mathrm{xE}\end{array}$ & $\begin{array}{l}\text { Debt Financing } \\
\mathrm{xD}\end{array}$ & $\begin{array}{l}\text { Retained Profits } \\
\mathrm{xR}\end{array}$ \\
\hline 1 & 70 & 0 & 130 \\
2 & 0 & 30 & 0 \\
3 & 0 & 500 & 0 \\
4 & 0 & 0 & 0 \\
5 & 0 & 270 & 130 \\
$\Sigma$ & 70 & 800 & 26 \\
\hline Mean $(\mathrm{x})$ & 14 & 160 & 676 \\
Mean $(\mathrm{x})^{2}$ & 196 & 25600 & \\
\hline Note. $(1 /(3-1)) . n .13,138.67=32,846.68 ;$ & & \\
$\mathrm{F}=32,846.68 / 213,240=0.15 ;$ & &
\end{tabular}

Since the calculated $\mathrm{F}$ is less than 3.89 , this study agrees with the proposition.

4.6 Ownership and Equity Financing in Relation to Performance

Changes in Equity Financing during the period were negligible to provide accurate statistical analysis to test the effects of Ownership Factor on the relationship between Equity Financing Strategy and the Performance Variables of SMEs.

\section{Conclusions}

Overall conclusions drawn from the findings of this study were that: (1) Equity Financing Strategy had empirical effect on the Performance of SMEs in Kakamega Municipality, Kenya. (2) Based on the findings of each Performance variables, the conclusion drawn was that there were positive significant relationships between Equity Financing Strategy and the Performance Variables: Profitability, Tax Liability, Value of the Firm, Solvency of the Firm and Growth in Sales. (3) The findings revealed that SMEs were "financially starved" to the extent of relying heavily on trade creditors to survive. Perhaps, this is the fundamental cause of their failure. (4) In particular, the findings showed that Equity Financing was not the most preferred financing strategy compared to Debt and Retained Profits Financing Strategies.

\section{References}

Baxter. (1967). Leverage, Risk of Ruin and the Cost of Capital. The Journal of Finance, 22(3), 395-403.

Berger, A. N., \& Bonaccorsidi, P. E. (2006). Capital Structure and Firm Performance: A New Approach to Testing Agency Theory and Application to the Banking Industry. Journal of Banking and Finance, 30, 65-101. http://dx.doi.org/10.1016/j.jbankfin.2005.05.015 
Bokea, et al. (1999). Micro and Small Enterprises in Kenya: Agenda for Improving the Policy Environment. Nairobi: International Centre for Economic Growth, 57-80.

Booth, L. et al. (2001). Capital Structures in Developing Countries. The Journal of Finance, LVI. http://dx.doi.org/10.1111/0022-1082.00320

Coleman, S., \& Cohn, R. (2001). Small Firms' use of Financial Leverage: Evidence from the 1993 National Survey of Small Business Finances. Journal of Business Entrepreneurship, 12(3).

Green et al. (2002). How do Small Firms in Developing Countries Raise Capital? Evidence from a Large-Scale Survey of Kenyan MSEs. Finance and Development Working.

John, V. (1880). On the Diagrammatic and Mechanical Representation of Propositions and Reasonings. Philosophical Magazine and Journal of Science.

Kayanula, \& Quartey. (2000). The Policy Environment for Promoting Small and Medium-Sized Enterprises in Ghana and Malawi.

Mackie, M. (1990). Do Taxes affect Corporate Financing Decisions? The Journal of Finance.

Modigliani, F., \& Miller, M. H. (1958). The Cost of Capital, Corporation finance and the Theory of Investment. American Economic Review, 48(3), 261-275.

Mugenda, \& Mugenda. (2003). Quantitative and Qualitative Approach. Nairobi: Acts Press.

Murinde et al. (2004). Patterns of corporate financing and financial system convergence in Europe. Review of International Economics, 12(4), 693-705. http://dx.doi.org/10.1111/j.1467-9396.2004.00476.x

Myer. (1977). Determinants of Corporate Borrowing. Journal of Financial Economics, (5), 147-76. http://dx.doi.org/10.1016/0304-405X(77)90015-0

Myers, S. C. (1984). The Capital Structure Puzzle. Journal of Finance, 39. http://dx.doi.org/10.1111/j.1540-6261.1984.tb03646.x

Myers, S. C., \& Majuluf. (1984). Corporate Financing and Investment Decisions when Firms have Information that Investors do not have. Journal of Financial Economics, 13. http://dx.doi.org/10.1016/0304-405X(84)90023-0

Nasiuma D. K. (2002). Survey Sampling Theory and Methods. Nairobi. University of Nairobi.

Oso, W. Y., \& Onen, D. (2009). Writing Research Proposal and Report. Nairobi: Sitemap.

Rajan, R. G., \& Zingales, L. (1995). What do we know about Capital Structure? Some evidence from international data. Journal of Finance, 50(5), 1421-1460. http://dx.doi.org/10.1111/j.1540-6261.1995.tb05184.x

Roden, D. M., \& Lewellen, W. G. (1995). Corporate Capital Structure Decisions: Evidence from leveraged buyouts. Financial Management, 24, 76-87. http://dx.doi.org/10.2307/3665536

Takatoshi, M. (2013). Financial Policy for SMEs in Japan Small and Medium Enterprise Agency. METI Government of Japan September.

Titman, S., \& Wessels, R. (1988). The Determinants of Capital Structure Choice. Journal of Finance, 43(1), 1-19. http://dx.doi.org/10.1111/j.1540-6261.1988.tb02585.x

Venn, J. (1880). On the Diagrammatic and Mechanical Representation of Propositions and Reasoning's. Philosophical Magazine and Journal of Science, 510(59). http://dx.doi.org/10.1080/14786448008626877

World Bank. (2006). Africa Development Indicators 2006: From Promises to Results. The World Bank: Washington, D.C.

Zeitun, \& Tian. (2007). Capital Structure and Corporate Performance: Evidence from Jordan. Australian Accounting Business and Finance Journal, 1(4).

\section{Copyrights}

Copyright for this article is retained by the author(s), with first publication rights granted to the journal.

This is an open-access article distributed under the terms and conditions of the Creative Commons Attribution license (http://creativecommons.org/licenses/by/3.0/). 